\title{
Sezaryen Sırasında Mesane Flebi İhmalinin Postpartum Klinik Değerlendirmesi
}

\author{
Postpartum Clinical Evaluation of Omission of Bladder Flap During Cesarean Section
}

Asiye UZUN ${ }^{1}$, Emrah AYDIN²ªtma ERSAN ${ }^{1}$, Adeviye ELÇI ATILGAN ${ }^{1}$, Şükriye Leyla ALTUNTAŞ ${ }^{1}$

1Department of Obstetrics and Gynecology, Medipol University, Faculty of Medicine, Istanbul, Turkey

2Department of Pediatric Surgery, Koç University Faculty of Medicine, Istanbul, Turkey

\section{Özet}

Amaç: Sezaryen (C/S), tüm dünyada jinekolog tarafından gerçekleştirilen en yaygın ameliyatlardan biridir. Bu çalışmanın amacı, bu özel hasta grubundaki deneyimlerimizi sunmak ve bir $\mathrm{C} / \mathrm{S}$ prosedürü sonrası mesane flebi olan ve olmayan hastaların erken ve geç sonuçlarını karşılaştırmaktır.

Gereç ve Yöntemler: Çalışmaya Ekim 2018 ile Ocak 2019 arasında C/S operasyonu yapılan hastalar dahil edildi. Haastaların demografik, özellikleri, perioperatif test sonuçları operatif özellikler, postoperatif sonuçlarıyla ile ilgili veriler toplanıldı. C/S kararı cerrah tarafından malplasentasyon, fetal distres, makrozmi, preeeklampsi, sefalopelvik uyumsuzluk, yumuşak doku distosisi olmak üzere fetal veya maternal endiskayonlarla verildi. Hastalar, Grup 1'de mesane flebi olan C/S, Grup 2 ise mesane flebi olmayan hastalardan oluşacak şekilde ikiye ayrıldı.

Bulgular: Çalışmaya ortalama yaşları $27.87 \pm 4$ yıl olan 63 hasta dahil edildi. Her iki gruptaki hastaların hiçbirinde mesane yaralanması yoktu. Grupların karşılaştırılması, grubun maternal yaş, ağırlık, vücut kitle indeksi (VKİ) ve gebelik haftası açısından istatistiksel olarak eşit olduğunu gösterdi. Grup 1 hastalarda mikrohematüri varlığ 1 anlamlı olarak daha yüksekti ( $\mathrm{p}=0.000$, OR 2.55, \% 95 CI 1.568-4.159) ve hemoglobin düzeylerinde istatistiksel olarak anlamlı düşüş vardı (Grup $10.91 \pm 1.48$ 'e karşı Grup $20.13 \pm 1.24$, p=0.026). Bununla birlikte, hematokrit değerlerindeki azalma istatistiksel olarak anlamlı değildi (Grup 1 1,78 \pm 6,84'e karşı Grup 2 0,63 4,09, p=0,423). Postoperatif rezidüel idrar ise mesane flebi olan hastalarda biraz daha yüksekti.

Sonuç: C/S sırasında mesane flebi kan kaybı, ameliyat süresi ve postoperatif semptomlar üzerinde olumsuz etkilere sahiptir. Bu nedenle, flebin çıkarılması hem hasta hem de cerrah için ameliyat sonrası konforu artıracaktır.

Anahtar Kelimeler: Sezeryan, Mesane flebi, Üriner retansiyon, Kanama

\section{Abstract}

Objective: Cesarean section $(\mathrm{C} / \mathrm{S})$ is one of the most common operation performed by the gynecologist throughout the world. The aim of this study is to present our experience in this particular group of patients and compare the early and late outcomes of the patients with and without a bladder flap after a $\mathrm{C} / \mathrm{S}$ procedure.

Material and Methods: Patients who underwent C/S surgery in our clinic between October 2018 and January 2019 were included in our study. Data were collected on demographics, perioperative test results, operative characteristics, postoperative complications and outcomes. The C/S decision was given by the surgeon per fetal or maternal problems such as, preeclampsia malpresentation, fetal distress, macrosomia. Patients were grouped into two as Group 1 comprised patients who had C/S with bladder flap while Group 2 included the patients without bladder flap.

Results: There were 63 patients included in the study with a mean age of $27.87 \pm 4.0$. None of the patients in either group had bladder injury. The comparison of the groups demonstrated the group were statistically equal in maternal age, weight, body mass index (BMI) and gestational week. The presence of microhematuria was significantly higher in Group 1 patients ( $\mathrm{p}=0.000$, OR $2.55,95 \%$ CI 1.568-4.159) and there was statistically significant decrease in the hemoglobin levels (Group $10.91 \pm 1.48$ vs Group $20.13 \pm 1.24$, p=0.026). However, the decrease in the hematocrit values were not statistical significant (Group $11.78 \pm 6.84$; Group $20.63 \pm 4.09$, p=0.423). The postoperative residual urine, on the other hand, was slightly high in patients with bladder flap.

Conclusion: Bladder flap during C/S has adverse effects on the blood loss, surgical time and postoperative symptoms. Hence, omitting the flap will improve the postoperative comfort both for the patient and the surgeon.

Keywords: Cesarean, Bladder flap, Urinary retention, Bleeding

Yazışma Adresi: Asiye UZUN, Medipol Üniversitesi Tıp Fakültesi, Kadın Hastalıkları ve Doğum Ana Bilim Dalı, İstanbul,Türkiye

Telefon: 05326464162, Mail: asiye.uzun@nisahastanesi.com

ORCID No (Sirasıly): 0000-0001-8322-6643; 0000-0001-7776-9684

Geliş Tarihi: 28.03 .2020

Kabul Tarihi:11.12.2020

DOI: $10.17517 /$ ksutfd. 710583 


\section{INTRODUCTION}

Cesarean section $(\mathrm{C} / \mathrm{S})$ is one of the most common operation performed by the gynecologist throughout the world. Per World Health Organization records, the C/S rate is around $30 \%$ in Europe and USA and the worldwide incidence has increased from $20.7 \%$ to 32.9 (1.2). The trend is almost similar in Turkey regardless of affords by the government. The higher rates of incidence come with higher rates of complications. This demonstrates the importance of predicting the risk factors for long term complications hence a wide variety of surgical techniques has been proposed. The most popular of those are single- or double-layer closure of the incision, use of a flap from bladder and using different types of abdominal incision. Among these, the main reason to prefer the bladder flap technique is to prevent the spread of infection through intrauterine cavity, to minimize the risk of injury and the ease of reaching the lower segment of the uterus (3.4). There are conflicting studies in the literature regarding the need to use a bladder flap during C/S (5-8). Hence, the aim of this study is to present our experience in this particular group of patients and compare the early and late outcomes of the patients with and without a bladder flap after a $\mathrm{C} / \mathrm{S}$ procedure.

\section{MATERIAL and METHODS}

\section{Study design}

After Institutional Review Board approval by local ethical committee was obtained with number 953 on September 13th, 2019 data of all cases admitted between October 2018 and January 2019 due to C/S were retrieved from hospital electronic medical records. All patients were consented prior to surgery. The study was conducted per the principals of Helsinki Declaration. Patients who underwent C/S surgery in our clinic between October 2018 and January 2019 were included in our study. Data were collected on demographics, perioperative test results, operative characteristics, postoperative complications and outcomes. The $\mathrm{C} / \mathrm{S}$ decision was given by the surgeon per fetal or maternal problems such as preeclampsia malpresentation, fetal distress, macrosomia. Patients were grouped into two as Group 1 comprised patients who had C/S withbladder flap while Group 2 included the patients without bladder flap.

\section{Surgical Technique}

A Pfannenstiel incision was performed under general anesthesia following $2 \mathrm{gr}$ intravenous cefalosporin. A formal $\mathrm{C} / \mathrm{S}$ procedure was performed. In order to prepare the bladder flap in Group 1 electrocautery was used to free the flap. The urinary catheter was removed at postoperative 8th hours, and an ultrasound was performed to check the residual urinary volume.

\section{Statistical Analysis}

Statistical analysis was performed with IBM SPSS Statistics 26.0.0 (Chicago, IL). The characteristics of the study sample were summarized by descriptive statistics, with dichotomous or ordinal data presented as percentages, and continuous data as means with standard deviations. The Kolmogorov-Smirnov test was used to demonstrate normal distribution. One-way ANOVA was used for homogeneity of variables, while the Student's T-test and Pearson correlation were used for parametric data. Mann-Whitney U, Wilcoxon, and Kruskal-Wallis tests and Spearman correlation were used for non-parametric data. Statistical associations were considered significant if the $\mathrm{p}$-value was $<0.05$.

\section{RESULTS}

There were 63 patients included in the study. The mean age of the patients was $27.87 \pm 4.49$ years and the mean gestational age was $38.27 \pm 1.66$ weeks. While the mean weight of the patients was $74.24 \pm 4.73 \mathrm{~kg}$, the mean body mass index was calculated as $30.57 \pm 1.17 \mathrm{~kg} / \mathrm{m} 2$. None of the patients had bladder injury. All patients were discharged at postoperative 2 rd day. The comparison of the groups demonstrated the group were statistically homogeneous in maternal age,

\section{Table 1. Demographics and characteristics of the study population}

\begin{tabular}{|c|c|c|c|}
\hline & Group 1 & Group 2 & $p$ \\
\hline Maternal age (years) & $28.91 \pm 4.60$ & $26.81 \pm 4.17$ & 0.063 \\
\hline Maternal weight (kg) & $73.97 \pm 4.62$ & $74.52 \pm 4.90$ & 0.650 \\
\hline Maternal BMI & $30.63 \pm 1.16$ & $30.52 \pm 1.21$ & 0.716 \\
\hline Gestational age (weeks) & $38.47 \pm 1.46$ & $38.06 \pm 1.84$ & 0.337 \\
\hline Operation time (minutes) & $37.25 \pm 2.72$ & $31.16 \pm 2.35$ & 0.000 \\
\hline Preoperative hemoglobin & $11.77 \pm 1.28$ & $11.45 \pm 1.26$ & 0.325 \\
\hline Preoperative hematocrit & $34.20 \pm 6.59$ & $34.24 \pm 3.39$ & 0.976 \\
\hline Preoperative leucocyte & $9.61 \pm 2.71$ & $12.30 \pm 4.80$ & 0.008 \\
\hline Postoperative hemoglobin & $10.85 \pm 1.19$ & $11.32 \pm 1.07$ & 0.106 \\
\hline Postoperative hematocrit & $32.41 \pm 3.11$ & $33.60 \pm 3.03$ & 0.129 \\
\hline Postoperative leucocyte & $15.02 \pm 4.38$ & $16.22 \pm 4.96$ & 0.309 \\
\hline Residual urine (ml) & $150.78 \pm 9.02$ & $130.23 \pm 4.34$ & 0.000 \\
\hline
\end{tabular}


weight, body mass index (BMI) and gestational week (Table 1). The surgery time was longer in the flap groups with statistical significant difference $(\mathrm{p}=0.000)$.

The presence of microhematuria was significantly higher in Group 1 patients ( $\mathrm{p}=0.000$, OR 2.55, 95\% CI 1.568 $4.159)$ and there was statistically significant decrease in the hemoglobin levels (Group $10.91 \pm 1.48$ vs Group $20.13 \pm 1.24$, $\mathrm{p}=0.026)$. However, the decrease in the hematocrit values did not statistical significance (Group $11.78 \pm 6.84$ vs Group 2 $0.63 \pm 4.09, \mathrm{p}=0.423)$. The postoperative residual urine, on the other hand, was slightly higher in patients with bladder flap.

\section{DISCUSSION}

Traditionally, bladder flap was accepted as a standard procedure during $\mathrm{C} / \mathrm{S}$. However, randomized control trials have been questioning its necessity. There is a tendency towards less invasive techniques during whole procedure (9). The first definition about it in the literature belongs to Pelosi et al. they proposed the correlation between minimal invasive approach and the time needed for healing $(10,11)$. Wood et al (12) compared the Pelosi's technique with Yale's traditional technique and stated that there is a decrease in bloodloss and operation time. However, they did not discuss the urinary symptoms. Hohlagschwandtner et al. found that in patients without bladder flapresulted in less bleeding as well as less operation time and decreased analgesia need postoperatively (13). On the other hand the studies mentioned above, there are many other those discuss the pros and cons of a C/S without a bladder flap $(5,7,14-19)$.

The main reasons for performing bladder flap during cesarean section are the prevention of infection in the intrauterine cavity, to minimize the bladder injury and the ease of reaching the lower uterine segment. The bladder flap is prepared from the lower uterine segment of the bladder, where the peritoneum is superficially dissected. Vesicouterine cavity is accepted as one of the most important peritoneal and extra peritoneal cavities in obstetric and gynecological surgery. It is defined as the field called excavatiovesico-uterina in international anatomical nomenclature and consists of submucosal areolar connective tissue, which can be easily dissected during surgery. However, recurrent cesarean adhesions and submesothelial fibrosis may occur. When the fluid accumulation exceeds $3.5 \mathrm{~cm}$, it is symptomatic and results in postoperative urinary symptoms (20).

One of the most important point in the long term follow up after $\mathrm{C} / \mathrm{S}$ is tissue healing. Hamar et al. demonstrated with MRI that although there is an increase in the thickness of uterus in postpartum 6th week, tissue healing would not start prior to 6th month (21). To our belief, omitting of an invasive procedure will improve this time. Moreover, dysuria after C/S is mostly due to manipulation of the bladder (22). The main cause of this the inflammatory process due to the tension of the bladder as a result of the maneuvers in the vesicouterine cavity as well as the thrombus the local edema of the tissue there.
Postpartum urinary retention has an approximate incidence of $3.2 \%$ to $24.2 \%$ after cesarean births (23). However, it is difficult to determine the sole effect of the surgical procedure itself since the anesthetics might have similar effects on the bladder. It is accepted that the residual bladder volume should be $>150 \mathrm{ml}$ or higher in order to diagnose postpartum urinary retention $(24,25)$. In order to measure the volume of the urine either ultrasound or intermittent catheterization is performed $(26,27)$.

There are limitations to our study. First of all, it is a retrospective review which includes an inherent bias. Second, larger volume of prospective randomized studies with longer follow up period is needed to better evaluate the outcomes. However, we believe that the current study will enlighten the current state in a given time frame.

Bladder flap during $\mathrm{C} / \mathrm{S}$ has adverse effects on the blood loss, surgical time and postoperative symptoms. Hence, omitting the flap will improve the postoperative comfort both for the patient and the surgeon.

\section{Conflict of Interest and Financial Status}

The authors declare that there is no conflict of interest to declare. The author(s) received no specific funding for this work.

\section{Research Contribution Rate Statement Summary}

The authors declare that, they have contributed equally to the manuscript.

\section{REFERENCES}

1. WHO. World Health Statistics 2010 : Health Status Indicators; World Health; Health Services - Statistics; Mortality; Morbidity; Life Expectancy; Demography; Statistics; World Health Organization.; 2010.

2. World Health Organization. WHO Statement on Caesarean Section Rates Caesarean section rates at the hospital level and the need for a universal classification system. WHO Libr Cat Data. 2015. doi:10.1016/j.rhm.2015.07.007

3. Faricy PO, Augspurger RR, Kaufman JM, Johnson JWC. Bladder injuries associated with cesarean section. J Urol. 1978;5847(17):57357-1. doi:10.1016/S0022

4. Eisenkop SM, Richman R, Platt LD, Paul RH. Urinary tract injury during cesarean section. Obstet Gynecol. 1982.

5. O’Neill HA, Egan G, Walsh CA, Cotter AM, Walsh SR. Omission of the bladder flap at caesarean section reduces delivery time without increased morbidity: A meta-analysis of randomised controlled trials. Eur J Obstet Gynecol Reprod Biol. 2014;174;20-6. doi:10.1016/j.ejogrb.2013.12.020

6. Berghella V, Baxter JK, Chauhan SP. Evidence-based surgery for cesarean delivery. Am J Obstet Gynecol. 2005;193(5):1607-17. doi:10.1016/j.ajog.2005.03.063

7. Tuuli MG, Odibo AO, Fogertey P, Roehl K, Stamilio D, MacOnes GA. Utility of the bladder flap at cesarean delivery: A randomized controlled trial. Obstet Gynecol. 2012;119(4):815-821. doi:10.1097/AOG.0b013e31824c0e12

8. Dahlke JD, Mendez-Figueroa H, Rouse DJ, Berghella V, Baxter JK, Chauhan SP. Evidence-based surgery for cesarean delivery: An updated systematic review. Am J Obstet Gynecol. 2013;209(4):294-306. doi:10.1016/j.ajog.2013.02.043 
9. Abalos E, Oyarzun E, Addo V, et al. CORONIS - International study of caesarean section surgical techniques: The follow-up study. BMC Pregnancy Childbirth. 2013;13:215. doi:10.1186/1471-2393-13-215

10. Phipps MG, Watabe B, Clemons JL, Weitzen S, Myers DL. Risk factors for bladder injury during cesarean delivery. Obstet Gynecol. 2005;105(1):156-60. doi:10.1097/01. AOG.0000149150.93552.78

11. Pelosi MA, Ortega I. Cesarean section: Pelosi's simplified technique. Rev Chil Obstet Ginecol. 1994;59(5):372-7.

12. Wood RM, Simon H, Oz AU. Pelosi-type vs. Traditional cesarean delivery: A prospective comparison. J Reprod Med Obstet Gynecol. 1999;44(9):788-95.

13. Hohlagschwandtner M, Ruecklinger E, Husslein P, Joura EA. Is the formation of a bladder flap at cesarean necessary? A randomized trial. Obstet Gynecol. 2001;98(6):1089-92. doi:10.1016/ S0029-7844(01)01570-8

14. Chigbu CO, Ezeome I V., Iloabachie GC. Non-formation of bladder flap at cesarean section. Int J Gynecol Obstet. 2006;95(3):284-5. doi:10.1016/j.ijgo.2006.08.010

15. Omar M, Farahat MA. Omission of the Bladder Flap Suggests Short Term and Long Term Benefits. Open J Obstet Gynecol. 2019;9:566-577. doi:10.4236/ojog.2019.95055

16. Aslan Cetin B, Aydogan Mathyk B, Barut S, Zindar Y, Seckin KD, Kadirogullari P. Omission of a Bladder Flap during Cesarean Birth in Primiparous Women. Gynecol Obstet Invest. 2018;83:564-568. doi:10.1159/000481283

17. Malvasi A, Tinelli A, Tinelli R, Cavallotti C, Farine D. The diagnosis and management of post-cesarean section hemorrhagic shock. J Matern Neonatal Med. 2008;21(7):487-91. doi:10.1080/14767050802042175

18. Malvasi A, Tinelli A, Guido M, Zizza A, Farine D, Stark M. Should the visceral peritoneum at the bladder flap closed at cesarean sections? A post-partum sonographic and clinical assessment. J Matern Neonatal Med. 2010;23(7):662-9.

\section{doi:10.3109/14767050903358363}

19. Malvasi A, Tinelli A, Tinelli R, Rahimi S, Resta L, Tinelli FG. The post-cesarean section symptomatic bladder flap hematoma: A modern reappraisal. J Matern Neonatal Med. 2007;20(10):70914. doi:10.1080/01674820701450573

20. Faustin D, Minkoff H, Schaffer R, Crombleholme W, Schwarz R. Relationship of ultrasound findings after cesarean section to operative morbidity. Obstet Gynecol. 1985. doi:10.1097/00132586198608000-00032

21. Hamar BD, Saber SB, Cackovic M, et al. Ultrasound evaluation of the uterine scar after cesarean delivery: A randomized controlled trial of one- and two-layer closure. Obstet Gynecol. 2007;110(4):808-13.doi:10.1097/01.AOG.0000284628.29796.80

22. Nagele F, Karas H, Spitzer D, et al. Closure or nonclosure of the visceral peritoneum at cesarean delivery. Am J Obstet Gynecol. 1996;174(4):1366-70. doi:10.1016/S0002-9378(96)70686-5

23. Liang CC, Chang SD, Chang YL, Chen SH, Chueh HY, Cheng PJ. Postpartum urinary retention after cesarean delivery. Int J Gynecol Obstet. 2007;99:229-232. doi:10.1016/j.ijgo.2007.05.037

24. Saultz JW, Toffler WL, Shackles JY. Postpartum urinary retention. J Am Board Fam Pract. 1991;243(5):673-80. doi:10.1097/01274882-200630020-00036

25. Yip SK, Sahota D, Pang MW, Chang A. Postpartum urinary retention. Acta Obstet Gynecol Scand. 2004;83(10):881-91. doi:10.1111/j.0001-6349.2004.00460.x

26. Lamonerie L, Marret E, Deleuze A, Lembert N, Dupont M, Bonnet F. Prevalence of postoperative bladder distension and urinary retention detected by ultrasound measurement. $\mathrm{Br} \mathrm{J}$ Anaesth. 2004;92(4):544-6. doi:10.1093/bja/aeh099

27. Rosseland LA, Stubhaug A, Breivik H. Detecting postoperative urinary retention with an ultrasound scanner. Acta Anaesthesiol Scand. 2002;46(3):279-82. doi:10.1034/j.1399-6576.2002.t011-460309.x 